KPACOTA I.B.

\title{
ДРУГИЙ ЕТАП РЕФОРМУВАННЯ ІНЖЕНЕРНИХ ВІЙСЬК ЗБРОЙНИХ СИЛ УКРАЇНИ (2000-2013 рр.)
}

На основі опублікованих джерел, а також особистого досвіду військової служби автора в інженерних військах Збройних Силах України, досліджуються другий етап реформування інженерних військ Збройних Сил України у період до 2013 р. в умовах реалізації Державної програми розвитку Збройних Сил України до 2005 р., Державної програми розвитку Збройних Сил України на 2006-2011 pp. та Державної комплексної програми реформування і розвитку Збройних Сил України на період до 2017 р. Порівняно зміни в організаційній структурі органів управління та з'єднань, військових частин та установ інженерних військ Збройних Сил України у цей період. Проаналізовано зміни співвідношення чисельності та кількості інженерних військ до чисельності Збройних Сил України.

Ключові слова: Інженерні війська, Збройні Сили України, реформування, співвідношення сил, організаційна структура, органи управління, інженерне забезпечення військ (сил).

Постановка проблеми. Реформування Збройних Сил (далі 3С) України, у тому числі ї складової - інженерних військ потребує додаткового вивчення. Особливо це стосується безпідставного скорочення інженерних з'єднань центрального та оперативного підпорядкування, відновлення яких потребує великих ресурсів, а також часу.

Аналіз досліджень і публікаџій дозволяє зробити висновок [6], що безвідповідальне "реформування, розвиток, трансформація" ЗС України, коли ці поняття підміняються скороченням військових частин бойового забезпечення, призводить до зниження оборонних спроможностей держави i, як наслідок, до втрати іiі територій.

Метою статті є порівняльний аналіз змін організаційної структури інженерних військ 3С України у період $2000-2013$ рр., а також вплив зменшення інженерних військ Збройних Сил України на стан виконання основних завдань інженерного забезпечення військ (сил).

Реформування інженерних військ ЗС Украӥни: Через низку причин, у тому числі фінансового характеру, Державна програма

Красота Ігор Васильович, науковий співробітник відділу науковометодичного забезпечення (проведення кадрової політики) Науково-методичного центру кадрової політики Міністерства оборони України, м. Київ.

(C) Красота I.B., 2018 
будівництва та розвитку 3С України на період до 2005 р. втратила свою актуальність задовго до іï завершення [1], тому Президент України у липні 2000 р. підписав Указ [2], згідно 3 яким програма реформування 3С України була скоригована й отримала назву: “Державна програма реформування та розвитку Збройних Сил України на період до 2005 р.”

Так розпочинається другий етап реформування інженерних військ ЗС України, нерозривно пов'язаний з процесом трансформаційних процесів 3С України.

У 2003 - 2004 рр. було проведено оборонний огляд [3] оцінки стану і готовності ЗС України до виконання завдань, за результатами якого було розроблено Стратегічний оборонний бюлетень України на період до 2015 року [4]. Метою України було набуття можливості для приєднання до НАТО, у той же час ЗС України повинні мати можливості щодо розгортання та утримування однієї бригади та до 3 - 5 окремих підрозділів рівня роти - батальйону у різних регіонах світу [5, с.32]. Відповідно 3 цим задумом інженерні війська були підпорядковані Командуванню сил підтримки 3С України [5, с. 46].

У грудні 2005 р. Указом новобраного Президента України було введено в дію нову Державну програму розвитку ЗС України на 2006-2011 рр., яка у цей період була профінансована лише на $75 \%$, економічні показники постійно відставали від реальних потреб ЗС України, тому реформи зазнали фіаско [6, с. 359]. Нове керівництво держави відмовилося від інтеграції з НАТО, але при цьому підтримувало позаблоковий статус, та в грудні 2012 р. прийняло нову Концепцію реформування і розвитку ЗС України на період до 2017 р. [7], відповідно з якою планувало подальше скорочення ЗС України, у тому числі інженерних військ ЗС України, зокрема: з'єднань, військових частин, установ та закладів центрального підпорядкування.

Розглянемо зміни у структурі та підпорядкуванні органів управління інженерними військами ЗС України у період 2000 2013 рр. (рис. 1). 3 кінця 90-х років по 2002 рік начальником інженерних військ ЗС України був генерал-лейтенант Воробйов Володимир Сергійович [8, с.17], його у 2002 р. замінив полковник (у подальшому генерал-майор) Ковальський Вадим Миколайович $[8$, c. 18$]$.

У 2004 р. відбувається інтеграції Управління начальника інженерних військ Генерального штабу ЗС України спочатку у квітні до Головного управління оперативного забезпечення 
3С України, потім у грудні до Командування сил підтримки ЗС України [9, с. 1], яке у подальшому було розформоване в 2010 р., а Центральне управління інженерних військ разом із військовими частинами та установами було підпорядковане Головному управлінню оперативного забезпечення ЗС України [10, с. 1]. У цей період начальниками інженерних військ були: генералмайор Бондар Богдан Володимирович (2006 - 2013 рр.) та полковник Пекельний Василь Леонідович (2013 - 2015 рр.).

У 2003 р. інженерно-саперні роти механізованих бригад переформовуються у групи інженерного забезпечення у складі двох рот, а в кожному механізованому батальйоні формуються інженерно-саперні взводи. Порівнюючи можливості реформованих інженерних підрозділів механізованих бригад, а саме: інженерносаперні роти та групи інженерного забезпечення, видно збільшення можливостей щодо дорожнього забезпечення руху підрозділів бригади. Також створення інженерно-саперних взводів збільшило можливості та автономності механізованих батальйонів щодо фортифікаційного обладнання позицій.

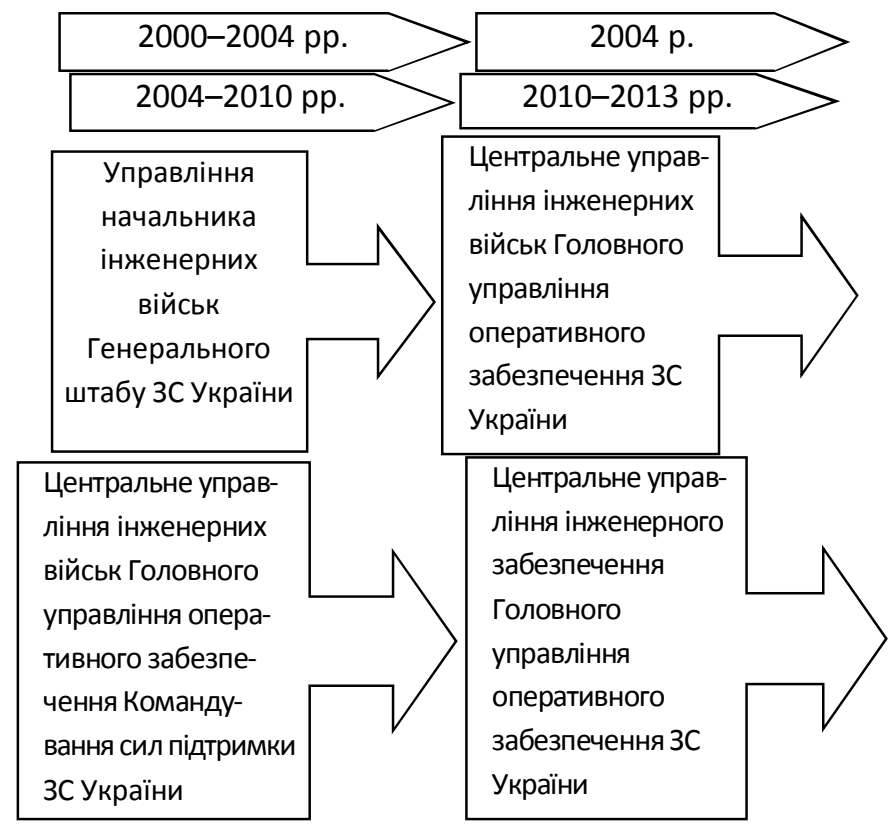

Puc. 1. Зміни структури та підпорядкування органів управляння інженерних військ у період 2000-2013 рр. 
Зазнали змін інженерні частини та підрозділи Сухопутних військ ЗС України, а саме у 1997 - 1998 рр. були ще дивізії та бригади зразка Радянської Армії [11, с. 24], їх переформовували у механізовані бригади оперативних командувань. До 2003 р. в механізованих бригадах були інженерно-саперні роти (рис. 2).

\section{Інженерно-саперна рота}
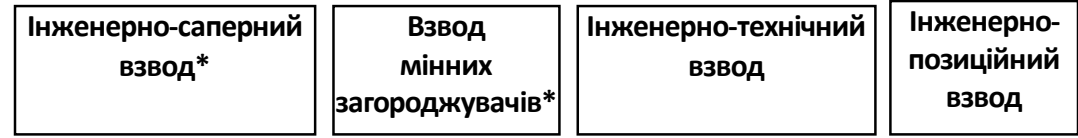

\begin{tabular}{|c|}
\hline $\begin{array}{c}3 \text { інженерно- } \\
\text { саперних } \\
\text { відділення }\end{array}$ \\
\hline Авт. (вант) - 6/3, \\
УР-83П - 2 к-т, \\
МП-Урал- 2 к-т, \\
ІМП-2 - 3 од., \\
КР-І - 3 к-т \\
\hline
\end{tabular}

\begin{tabular}{|c|c|}
\hline $\begin{array}{c}3 \text { відділення } \\
\text { інженерних } \\
\text { загороджень }\end{array}$ & $\begin{array}{c}2 \text { відділення } \\
\text { інженерної } \\
\text { техніки }\end{array}$ \\
\hline $\begin{array}{l}\text { ГМЗ - 6/3 од., } \\
\text { Авт. (вант) - } 6 \text { од., } \\
\text { 2-ПН-4М - } 6 \text { од. }\end{array}$ & $\begin{array}{l}\text { Авт.(вант) - } 12 \text { од., } \\
\text { ІМР - } 2 \text { од., } \\
\text { Авт.(вант) }-4 \text { од., } \\
\text { МТУ - } 2 \text { од., } \\
\text { ТММ - } 1 \text { к-т }\end{array}$ \\
\hline
\end{tabular}

\begin{tabular}{|l|}
\hline \multicolumn{1}{|c|}{5 відділень } \\
\hline ЕОВ-4421 - 2 од. \\
Автокран 5-7 т. - 4 од., \\
ПЗМ - 2 од., \\
ВФС-2,5 - 1 од., \\
Авт. (вант) - 10, \\
2ПН-5,5 - 2 од., \\
КМТ-7 - 6 од., \\
КМТ-6 - 18 од. \\
\hline
\end{tabular}

Рис. 2. Структура інженерно-саперної роти окремої механізованої бригади військового округу (ОК)

\section{Зміни у співвідношенні інженерних військ ЗС України}

Протягом 2000 - 2013 рр. чисельність ЗС України скоротилася на 232 тис. посад, у тому числі на 185 тис. посад військовослужбовців та на 47 тис. посад цивільного персоналу. Разом із 3С України інженерні війська також зазнали суттєвого скорочення на 4499 посад, особливо це стосувалося військових частин та установ центрального та оперативного підпорядкування. Хоча співвідношення інженерних військ до загальної чисельності 3С України у 2005 р. збільшилось на 0,9\% за рахунок збільшення військової ланки інженерних підрозділів, на кінець 2013 р. частка інженерів знизилась на $0,5 \%$ (таблиця 1$)$. 
Зміни співвідношення інженерних військ ЗС Украӥни до загальної чисельності ЗС України у 2000-2013 pp.

\begin{tabular}{|l|c|c|c|c|c|}
\hline $\begin{array}{l}\text { Чисельність за роками, } \\
\text { тис. осіб }\end{array}$ & $\mathbf{2 0 0 0}$ p. & $\mathbf{2 0 0 3}$ p. & $\mathbf{2 0 0 5}$ р. & $\mathbf{2 0 1 3}$ р. & Різниця \\
\hline $\begin{array}{l}\text { Всього у ЗС України, у тому } \\
\text { числі: }\end{array}$ & 400,0 & 390,0 & 245,0 & 165,5 & $-234,5$ \\
\hline Військовослужбовці & 310,0 & 305,0 & 180,0 & 120,9 & $-189,1$ \\
\hline Працівники ЗСУ & 90,0 & 65,0 & 65,0 & 44,6 & $-45,4$ \\
\hline $\begin{array}{l}\text { Всього за інженерні війська 3С } \\
\text { України, у тому числі: }\end{array}$ & 9,1 & 8,3 & 7,8 & 3,0 & $-6,1$ \\
\hline Військовослужбовці & 7,6 & 6,8 & 6,3 & 2,1 & $-5,1$ \\
\hline Працівники ЗСУ & 1,5 & 1,5 & 1,4 & 0,9 & $-0,6$ \\
\hline $\begin{array}{l}\text { Загальна частка інженерних } \\
\text { військ ЗС України, у тому числі: }\end{array}$ & $\mathbf{2 , 3 \%}$ & $\mathbf{2 , 1 \%}$ & $\mathbf{3 , 2 \%}$ & $\mathbf{1 , 8 \%}$ & $-0,5$ \\
\hline Частка військовослужбовців & $\mathbf{2 , 5 \%}$ & $\mathbf{2 , 2 \%}$ & $\mathbf{3 , 5 \%}$ & $\mathbf{1 , 7 \%}$ & $-1,5$ \\
\hline Частка працівників ЗСУ & $\mathbf{1 , 6 \%}$ & $\mathbf{2 , 3 \%}$ & $\mathbf{2 , 2 \%}$ & $\mathbf{2 , 0 \%}$ & $+0,4$ \\
\hline
\end{tabular}

Зменшення частки інженерних військ у складі ЗС Украӥни

Розглянемо, як відбувалося так зване реформування, а насправді скорочення інженерних військ ЗС України у 2001 2013 pp.

209 інженерно-саперну бригаду (м. Кременчук) у 2001 р. переформовано в 803 інженерний полк (м. Кременчук), який в 2003 р. розформовано.

1500 Центр підготовки інженерних військ (м. Кам'янецьПодільський) у 2001 р. переформовано в Навчальний центр підготовки інженерних військ (м. Кам'янець-Подільський), який в 2012 р. розформовано [12].

91 інженерно-саперну бригаду (м. Охтирка) передано в підпорядкування в Північне ОК, в 2004 р. переформовано в 91 інженерний полк (м. Охтирка) [13].

23 понтонно-мостова бригада переформована в 2002 р. у 808 понтонно-мостовий полк.

Військовий інженерний інститут при Подільській державній аграрно-технічній академії (м. Кам'янець-Подільський) переформований в 2006 р. в Факультет військової підготовки Кам'янецьПодільського національного університету ім. І. Огієнка [14], який 
у 2012 р. розформовано, а підготовку офіцерів тактичного рівня переведено до складу Академії сухопутних військ імені гетьмана П. Сагайдачного (м. Львів).

У 2010 р. було сформовано військовий коледж сержантського складу (м. Кам’янець-Подільський), який у 2012 р. було розформовано [15].

У 2003 р. розформовані: 210 понтонно-мостова бригада (м. Київ) [16], 101 понтонно-мостовий полк (м. Кам'янець-Подільський), 73 інженерний полк (м. Дніпродзержинськ) [17], 137 інженерний полк (м. Бахчисарай).

10 інженерно-саперна бригада (м. Самбір) переформована в 2003 р. в 703 інженерний полк, 14 інженерний полк (м. Острог) було розформовано у 2004 p. [18], а 11 інженерний полк (м. Бровари) у 2012 р. [19].

703 інженерний полк (м. Самбір) планувалось розформувати до кінця 2013 р., але цьому завадила нездана техніка та озброєння полку.

Таким чином, станом на 31 грудня 2013 р. в інженерних військах 3С України залишилося тільки три інженерних полки та один понтонно-мостовий полк. Крім того, була ліквідована система підготовки фахівців інженерних військ ЗС України, залишки якої переведено до м. Львів.

У 2003 - 2010 рр. типовий інженерний полк армійського корпусу [20] мав у своєму складу п'ять батальйонів (інженерносаперний, інженерно-дорожній, інженерно-технічний, інженернопозиційний та понтонно-мостовий батальйони) та окремі підрозділи (рис. 3)

Інженерний полк

армійського корпусу

\begin{tabular}{|c|c|c|c|c|}
\hline $\begin{array}{c}\text { Інженерно- } \\
\text { саперний } \\
\text { батальйон }\end{array}$ & $\begin{array}{c}\text { Інженерно- } \\
\text { дорожній } \\
\text { батальйон }\end{array}$ & $\begin{array}{c}\text { Iнженерно- } \\
\text { технічний } \\
\text { батальйон }\end{array}$ & $\begin{array}{c}\text { Iнженерно- } \\
\text { позиційний } \\
\text { батальйон }\end{array}$ & $\begin{array}{c}\text { Понтонно- } \\
\text { мостовий } \\
\text { батальйон }\end{array}$ \\
\end{tabular}

Рис. 3. Структура типового інженерного полку армійського корпусу 
Інженерно-саперний батальйон полку мав три інженерносаперних та дві роти інженерних загороджень, був призначений для улаштування інженерних загороджень і здійснення руйнувань, подолання інженерних загороджень і руйнувань, виконання інших завдань у ході бойових дій в інтересах об'єднання, а також посилення загальновійськових з'єднань та частин тактичної ланки.

Інженерно-дорожній батальйон полку мав дві інженернодорожні роти, інженерно-мостобудівельну роту та роту розгороджень, був призначений для підготовки та утримання шляхів, будівництва (відновлення) низьководних мостів через водні перешкоди, а також дій в загонах забезпечення руху при безпосередньому забезпеченні висування з'єднань, частин і загонів розгородження при забезпеченні рейдових (штурмових) дій.

Інженерно-технічний батальйон полку мав у складі роти обладнання пунктів управління, двох інженерно-маскувальних рот, взводу польового водопостачання та взводу інженерних конструкцій, був призначений для фортифікаційного обладнання районів розгортання пунктів управління об'єднання, обладнання та утримання пунктів водопостачання, а також для виконання інженерних заходів маскування військ і об’єктів.

Інженерно-позиційний батальйон полку мав в складі три інженерно-позиційних роти та був призначений для виконання завдань $з$ фортифікаційного обладнання позицій, смуг оборони, районів розташування військ.

Понтонно-мостовий батальйон полку був призначений для обладнання та утримання мостових і поромних переправ через водні перешкоди.

Отже, інженерний полк в оперативно-тактичній ланці (армійський корпус) надавав самостійності загальновійськовим з'єднанням і частинам (в першу чергу тим, які входили до складу Об'єднаних сил швидкого реагування) у виконанні завдань інженерного забезпечення в різних видах бою.

У подальшому в 2011 р. інженерні полки було переформовано в окремі полки оперативного забезпечення, в яких було зменшено можливості полку щодо інженерного забезпечення за рахунок збільшення можливостей підрозділів РХБ захисту.

Висновки. 1. На кінець 2013 р. частка інженерних військ ЗС України знизилась до $1,8 \%$, що призвело до втрати ними практичних спроможностей інженерного забезпечення оперативних 
та оперативно-стратегічних угруповань, а рівень органів управління інженерними військами ЗС України поступово знизився від Генерального штабу ЗС України до Головного управління оперативного забезпечення ЗС України.

2. Створення штатних підрозділів інженерних військ в тактичній (батальйон) та оперативно-тактичній (бригада) ланці як готових елементів бойового порядку, а саме: рухомих загонів загородження, загонів забезпечення руху, загонів розмінування $\mathrm{i}$ розгородження дозволило збільшити самостійність та мобільність, що було вимогою часу, а також зберегти інженерні підрозділи військової ланки.

3. Через оборонну направленість реформ було надано пріоритет розвитку таким підрозділам інженерних військ, як позиційні, загородження та інженерно-саперні (до 70 - 80 \% від загальної чисельності інженерних полків).

4. Реформування інженерних військ ЗС України є окремою складною темою, яка потребує ретельного подальшого дослідження.

1. Указ Президента України «Про рішення Ради національної безпеки і оборони України від 31 жовтня 2000 року "Про хід виконання у 1997-2000 роках Державної програми будівництва та розвитку Збройних Сил України на період до 2005 року” від 15.11.2000 р. № 1237/2000 : [Електрон. ресурс]. Режим доступу : http://zakon5.rada.gov.ua/laws/show/1237/2000.

2. Указ Президента України «Про рішення Ради національної безпеки і оборони України від 29 травня 2000 року "Про Державну програму реформування та розвитку Збройних Сил України на період до 2005 року” від 28 липня 2000 р. № 927/2000: [Електрон. ресурс].- Режим доступу: http://zakon3.rada.gov.ua/laws/ show/927/2000

3. Закон України від 18.11.2004 № 2198-IV «Про організацію оборонного планування»: [Електрон. ресурс]. Режим доступу: http://zakon4.rada.gov.ua/laws/show/2198-15

4. Указ Президента України № 670/2004 «Про рішення Ради національної безпеки і оборони України від 17 червня 2004 року “Про Стратегічний оборонний бюлетень України на період до 2015 року”» від 22.06.2004 : [Електрон. ресурс]. Режим доступу: http://zakon2.rada.gov.ua/laws/show/670/2004

5. Стратегічний оборонний бюлетень України на період до 2015 року: (Біла книга України), Міністерство оборони України, - К. Аванпост: 2004. - 96 с.

6. Історія українського війська: підручник / П.П. Ткачук, С.В. Сидоров, А.І. Харук «та ін.». - Львів: НАСВ, 2017. $407 \mathrm{c}$.

7. Про рішення Ради національної безпеки і оборони України від 29 грудня 2012 року "Про Концепцію реформування і розвитку Збройних Сил України на період до 
2017 року" / Указ Президента України 29 грудня 2012 року № 772/2012: [Електрон. ресурс]. - Режим доступу: http://zakon4.rada.gov.ua/laws/show/772/2012/ paran2\#n2

8. Галузевий державний архів Міністерства оборони (далі - ГДА МО) України, ф. 6157, оп. 49338, спр. 1, 20 арк.

9. ГДА МО України, ф. 5622, оп. 49365, спр. 1, 15 арк.

10. ГДА МО України, ф. 5622, оп. 49687, спр. 1, 10 арк.

11. Штат окремої механізованої бригади військового округу / інв. номер. 322/7/575 від 26.10.2010, 65 арк.

12. ГДА МОУ, ф. 6382, оп. А1П, спр. 1, арк. 37

13. ГДА МОУ, ф. 2076, оп. 18908, спр. 1, арк. 6

14. ГДА МОУ, ф. 5566, оп. 54225, спр. 2, арк. 79

15. ГДА МОУ, ф. 6403, оп. 53409, спр. 1, арк. 13

16. ГДА МОУ, ф. 606, оп. 30504, спр. 2, арк. 115

17. ГДА МОУ, ф. 1330, оп. 32351, спр. 1, арк. 151

18. ГДА МОУ, ф. 3204, оп. 32616, спр. 11, арк. 152

19. ГДА МОУ, ф. 599, оп. 53900, спр. 1, арк. 53

20. Лекція начальника інженерних військ 3С України. Тема: "Інженерне забезпечення військ оперативного командування в операціях" - Київ : 2003.

Надійшла до редколегії 22.01.2018 р.

Рецензент: Л.П. Кривизюк, кандидат історичних наук, доцент, провідний науковий співробітник Наукового центру Національної академії сухопутних військ імені гетьмана Петра Сагайдачного, м. Львів.

\section{Krasota Ihor \\ SECOND STAGE OF THE REFORMING THE ENGINEER TROOPS OF THE ARMED FORCES OF UKRAINE (2000-2013).}

On the basis of published sources, as well as personal experience of the author's military service in the engineer troops of the Ukrainian Armed Forces, the article examines the second stage of the reforming the engineer troops of the Ukrainian Armed Forces in the period of 2013 in the context of the implementation of the State Programs of Development of the Armed Forces of Ukraine of 2005, the State Program of Development of the Armed Forces of Ukraine for 2006-2012, and the State Integrated Program for Reformation and Development of the Armed Forces of Ukraine for the period up to 2017. The work compares changes in the organizational structure of command and control organizations and formations, military units and engineer troops authorities of the Ukrainian Armed Forces during this period. It also analyzes the changes in the balance of the strength of engineer troops and the strength of the Armed Forces of Ukraine. A reduction of the slice of engineer troops within the Armed Forces of Ukraine that influenced the organization of carrying out the main tasks of engineer support of troops (forces) in the period from 2000 to 2013 is also examined.

Key words: Engineer troops, the Armed Forces of Ukraine, reformation, balance of forces, organizational structure, command and control organizations, engineer support of troops (forces). 